$\mathrm{Oz}$

$1-1-1990$

\title{
The Negative Mirror and Critical Memory
}

Paul Armstrong

Follow this and additional works at: https://newprairiepress.org/oz

(c) (i) $\Theta(9$

This work is licensed under a Creative Commons Attribution-Noncommercial-No Derivative Works 4.0 License.

\section{Recommended Citation}

Armstrong, Paul (1990) "The Negative Mirror and Critical Memory," Oz: Vol. 12. https://doi.org/10.4148/ 2378-5853.1201

This Article is brought to you for free and open access by New Prairie Press. It has been accepted for inclusion in Oz by an authorized administrator of New Prairie Press. For more information, please contact cads@k-state.edu. 


\title{
The Negative Mirror and Critical Memory
}

\author{
Paul Armstrong
}

Elsewhere is a negative mirror. The Traveler recognizes the little that is his, discovering the much he has not had and will never have.

- Italo Calvino, Invisible Cities

Marco Polo's negative mirror is, more or less, like one of the concave parabolic surfaces used to concentrate the parallel solar rays into a unique point, giving them a previously unknown shining. In a similar manner the traveler's gaze will bend the apparently isolated and undifferentiated facets of a place and tie them together in a more intense reality thereby revealing the "genius loci," which is a projection of human conscience. Places which display traces of human action (past or present) become teleonomic, i.e., illustrative of an intention which is always the print of human action. The "human intention" can be discovered even in the natural landscape, as in the traditional toponymy of mountain peaks, rivers, woods, etc. Ancient geographical names often refer to characters and events which work according to the finalist causality typical of mythical thought. In a sense, the negative mirror reveals the autochthonous or indigenous character of place. ${ }^{1}$

In describing his urban architecture, Peter Eisenman uses the term dislocation. Eisenman accepts the mnemonic potency of architecture, but, at the same time, poses the paradox of architecture as a mnemonic device while presenting itself as dislocated from its continuity with time. Projects such as the housing pro- the recently christened Wexner Center for the Arts of Ohio State University explore the process of "excavating the site" in order to rediscover the traces of the past (whether the Mercator grid or the "reconstructed" foundations of an $\mathrm{Ar}$ mory). Past and present are brought together in simultaneous juxtaposition not a literal archeology of the site, but in- stead, a critical reconstruction of the past. In Eisenman's terms, architecture can be simultaneously autochthonous and autonomous.

Critical memory is the past reinterpreted and reconstructed. Like the negative mirror, in Eisenman's definition of dislocation, isolated and undifferentiated facets of time and place are synthesized into a more intense reality. An unique telos emerges with its own syntactic reading a referent to the past serving memory and a dislocation in time aspiring to be devoid of all mnemonic association.

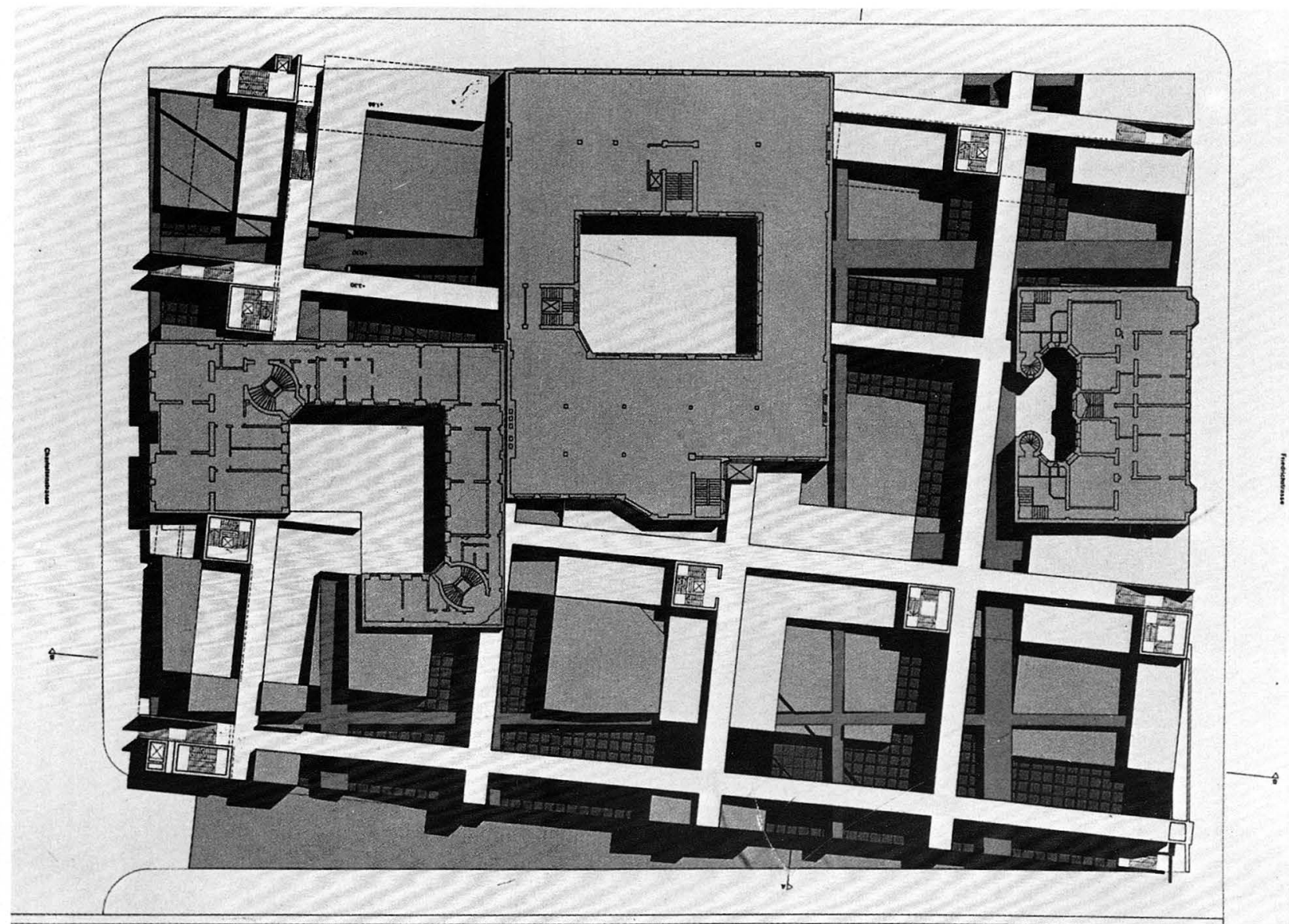

Figure 1: Peter Eisenman and Jaquelin Robertson, Restricted International Competition Living and Working in Southern Friedrichstadt, Block 5 Berlin, Site Plan. (Courtesy Rizzoli International Publications). 


\section{The City and Collective Memory}

The time of each man is limited; the future, therefore, must be the present.

- Aldo Rossi,

The Arcbitecture of the City

In his preface to The Architecture of the City, Eisenman cites Rossi's description of the city as "a collective artifact" which juxtaposes the humanist view of the evolution of the city as a sort of accretion based upon natural law versus moder nism's reductive scientism which seeks to intervene clinically in the city's historical and natural evolution. "In this heroic climate of modernism the city of modern architecture, supposedly born out of a rupture with history, was progressively propelled by that very history toward the vision of a sanitized utopia."'2

Hence, Eisenman presents the dichotomous condition of the city as an archeological artifact and of the city as an autonomous structure which coexis within the context of the present. In con trast to the humanist architect of the six teenth century, and the functionalist ar chitect of the twentieth century, Rossi's architect would seem to be an unheroic, autonomous researcher distanced from the object of his analysis who no longer believes in science or progress.

\section{Eisenman continues:}

The new time of architecture is ... that of memory, which replaces history. The individual artifact for the first time is understood within the psychological construct of a collective memory. Time as collective memory leads Rossi to his particular transformation of the idea of type. With the introduction of memory into the object [the city], the object comes to embody both an idea of itself and a memory of a former self. Type is no longer a neutral structure found in history but rather an analytical and experimental structure which now can be used to operate on the skeleton of history; it becomes an apparatus, an instrument for analysis and measure ... Memory fuses with history to give type-form a significance beyond that of an original function. Thus, typology, which previously consisted only of the classification of the known, now can serve as a catalyst for invention. It becomes the essence of design for the autonomous researcher. $^{3}$

The humanist view of the evolutionary process of "accretion" of the city and collective memory is exemplified by Rossi's description of the city of Split in Yugoslovia. Rossi points out that as the city of Split grew up within the walls Diocletian's Palace, it gave new uses and new meanings to unchangeable forms. Rather than subsuming or obliterating the ancient palace, the city accomodated the existing architecture within the context of its own transformation in a type of organic symbiosis. According to Rossi, this is symbolic of the meaning of the architecture of the city, where "the broadest adaptability to multiple functions corresponds to an extreme precision of form." ${ }^{4}$ Therefore, history, as an accretion of collective memory, exists so long as an object is in use; that is, so long as a form relates to its original function. However, when form and function are severed, and only form remains vital, history shifts into the realm of memory. Eisenman writes that the singular form of Split now not only signifies its individuality, but at the same time, is a syntactic record of events that are part of a collective (urban) memory. History, thereby, comes to be known through the relationship between a collective memory of events, the singularity of place, and the sign of the place as expressed in form.

Although Eisenman recognizes the significance of history and fundamentally agrees with Rossi's analogue of the "collective" house as a mnemonic device, he remains sceptical of historic convention. The Wexner Center for the Visual Arts at Ohio State University is perhaps the clearest embodiment of the philosophical principles (rooted in the syntactic dialec tics of deconstruction espoused by the semiologists and post-structuralists) which have consistently governed his ouevrefor almost three decades. Thomas Fisher writes that at almost every turn in the Wexner Center, "Eisenman confronts our design conventions and challenges our often unexamined assumptions, creating a building that aims not to provide comfort or consolation, but one that tries, successfully, to shake us from the complacency of our convictions." 5

Fisher observes that in the Wexner Center Eisenman challenges historicism and the belief in the communicative power of historical styles. The fragments of the armory that form one side of the Wexner Center represent an analogy to the fragmentation of the past that historicists have, ironically, brought upon themselves by asserting that history is a matter for specialized, scientific study. If history, then, is perceived by most people to be fragmented, like the armory towers, into disconnected pieces of information, does the use of historic styles any longer have meaning? Eisenman also questions whether a related view of the past is desirable or even possible if language itself can be used to create false unity and to suppress dissention.

Eisenman effects the transition from the historic, chronological notion of time to the psychological condition of time with reference to the memory of the city as a succession of events. In Eisenman's parlance, if time in the chronological sense belonged to a classical context, and in the historicist sense to a modernist context, then once associated with memory rather than history, it moves into a psychological context. Thus, Eisenman defines an existential condition which dif ferentiates the form of the city as urban history from its memory as a succession of events and redefines time within a psychological condition in which the ar chitect is separated from the events of history in his role as analyst and, paradoxically, is a catalyst to the process of history. Eisenman illuminates the existential condition of "dislocation" through the persona of Rossi's architect. Rossi's architect is both a participant within the context of collective memory and a voyeur positioning himself as an "objective" observer beyond the demarcations of time and memory. Whereas the humanist conception attempted an integration of subject (the architect) and the object (the city), the modernist conception polemically attempted their separation. The problematic nature of the practice of modern architecture with respect to the theory of modernism has to do precisely with its inability to effect this separation and thus its contamination with imperatives from the humanist conception.

A modern example of intervention in the historic city is cited in Michael Graves' "Roma Interrotta" of $1978^{\circ}$. As architectin-residence at the American Academy in Rome, Graves invited twelve architects, including Colin Rowe, James Stirling, and Leon Krier, to take one of the twelve segments of the Nolli map and redesign that segment of Rome in any way they chose. In The Elusive City Jonathan Barnett records that using a collage technique advocated by Rowe, the diverse results suggested "interventions in Rome after a lapse of time."7 Many of the participants responded in a predictable, yet highly individualistic, manner. Stirling, for instance, used variants of his own buildings to compose his own sector. Rowe and his associates based their proposals on the Nolli map itself, albeit with a more regular and repetitive quality of the new elements. However, it was Leon Krier who designed perhaps the most unexpected interpolations. Modifying St. Peter's Square, the Via Corso, the Campidoglio and the Piazza Novona with different versions of the same structure, Krier's drawings for Roma Interrotta seem to mark a transition in his work from the design of projects for monumental, symmetrical megastructures ${ }^{8}$ to a monumental city design of more conventional kind. According to Barnett, Krier's planning proposals resemble the texture of Paris in 


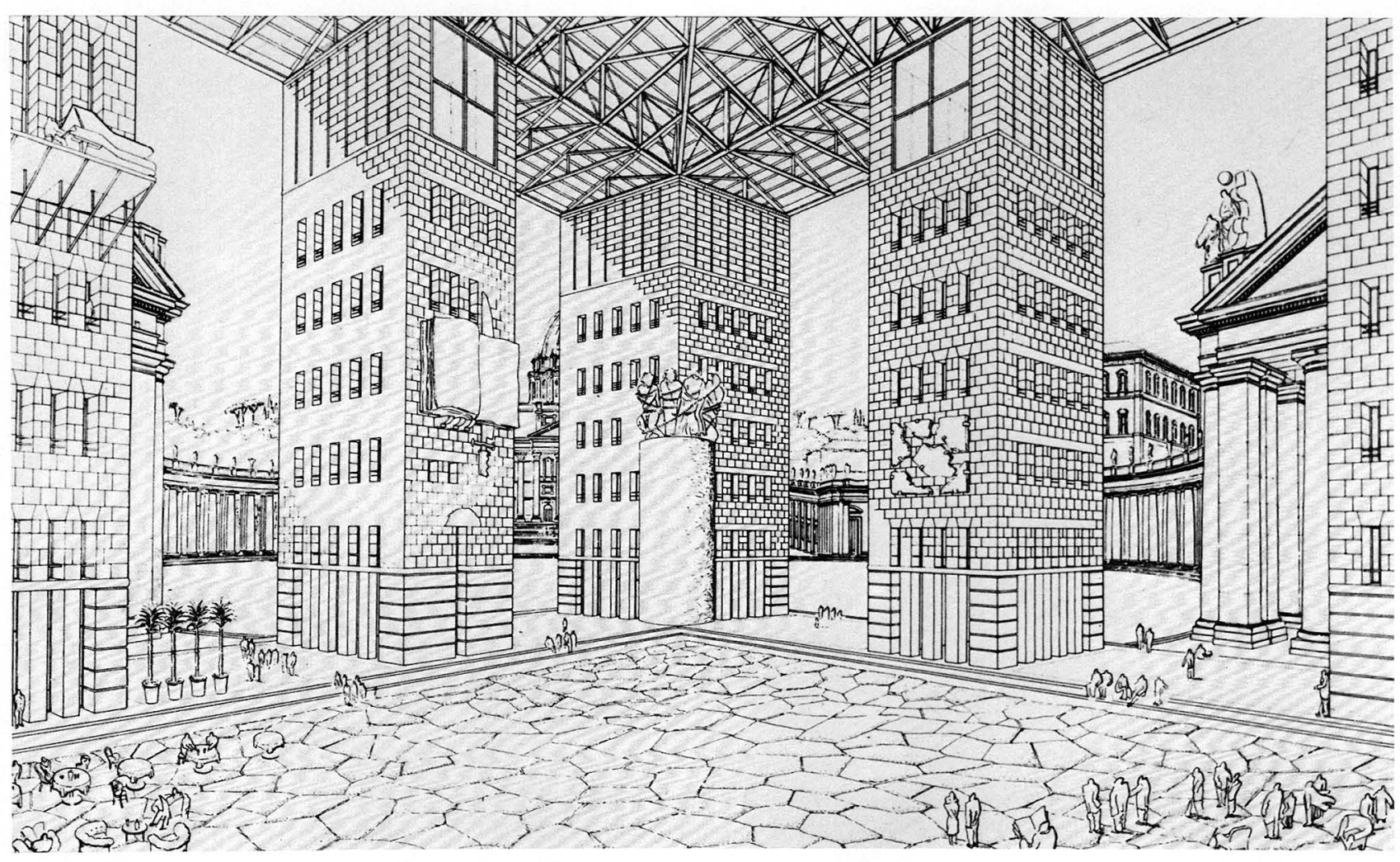

Figure 2: Leon Krier, Roma Interotta 1977, St. Peter's Square, Perspective. (Courtesy AD Editions, Ltd.).

which monumental boulevards section off districts into strongly articulated precincts, more regular than in a medieval city but just as distinct.

Krier rejects the infinite axial extension of earlier Baroque plans and, like Camillo Sitte, seems to consider the enclosure of space more important than the vista. The intersections of two major boulevards are often articulated by a monumental, covered outdoor space where the roof is supported by a group of buildings. This is a totally nontraditional concept that was not even technically possible until the late nineteenth century.

Unlike Eisenman's dialectical.views expounding the dislocation of postmodernist architecture, Krier presents a more antiquarian polemic as a reaction to the decentralization and tabla raza advocated by proponents of modernism. The concept of the modern city sought to try through a combinaton of greenbelts and orderly clusters of development. In a perverse way, Ebenezer Howard's "Garden City" has become a model for today's suburban developments in which the infrastructure of the older city has been imagined to "wither away." 10 Linked by airports and roadways, the new, decentralized urban center has become a complex of offices, factories and warehouses, clusters of hotels, and regional shopping centers.

The concept of the modern city was also a reaction against the way cities had evolved during the nineteenth century. The old forms of urban organization provided by street and square were discarded in favor of individual buildings in a parklike setting. Except for a few structures retained for historical or sentimental reasons, the modernists believed that cities would be completely renewed. Since there would be no incongruity between old buildings and new, modernist proponents believed that stylistic unity would be conferred upon cities through a single, unified architec- tural expression replacing the stylistic diversity characteristic of nineteenth- and early-twentieth-century buildings.

\section{The Negative Mirror}

In Maurilla the traveler is invited to inspect the town and also to look at certain picture postcards which show what it used to be like: the very same square with a chicken in place of the bus station, the music pavillion instead of the flyover, two young ladies with parasols instead of the ammunition plant. To avoid disappointing the locals, the traveller must praise the town on the postcard and say how he prefers it to the present-day town, being careful though to keep his expressions of regret within the well-defined limits laid down by convention.

$$
\text { - Italo Calvino }
$$

Historically, the erosion of urban space in twentieth-century town planning has occurred precipitously over a period of many centuries. In Urban Space Rob Krier contends that the demise of the necessity of fortification and the demolition of city walls with the introduction of new military technology and new tactical patterns for warfare after the French Revolution ushered in an era in which all assumptions and empirical principals about town planning were fundamentally questioned. Rendered obsolete, city walls had once played a well-defined role in townplanning. As "regulators" of urban space, the absolute necessity of protection and security has imposed a total discipline on every aspect of the construction, rebuilding and expansion of the town. The decline of the city wall coincided with the onset of industrial development, which forced cities into unprecedented growth. Unchecked, cities spread over the surrounding countryside in a chessboard pattern, which was almost always used as the basis for new settlements. ${ }^{11}$

According to Krier, no significant variation in this method of town planning was proposed until about 1900 with the publications of Ebenezer Howard's Garden Cities of Tomorrow, Soria y Mata's concept of the linear city, Tony Garnier's Cite' industrielle, and Camillo Sitte's Stadtebau nacb seinen kunstleriscben Grundsatzen. Although never fully realized, each of these proposals was to have an enormous impact upon modern planning strategies and formed the underpinnings of the rhetoric for modern urban theoretical premises.

By the 1920's, rapid growth and unregulated industrialization during the nineteenth century created deplorable living conditions for the poor in large slum districts that occupied large urban areas. Although some of the worst sanitation and water-supply problems had been addressed, laws regulating development were not stringent and often unenforced. The clarion call of modernist architecture and urban planning was based upon Le Corbusier's redefinition of central Paris, known as the Voisin Plan, exhibited in 
1925. In this proposal, the business center of Paris is replaced by eighteen sixty-floor skyscrapers and three clusters of luxury apartments accessed by a limited-access highway driven directly through the heart of the city. Autocratic and bold, the Voisin Plan was not based on the functional organization or the priorities of real cities, nor was it an egalitarian proposal designed to obliterate and restructure the deteriorating working-class districts of Paris. Ironically, Le Corbusier's original vision of a new order was designed for the elite. $^{12}$

It wasn't until the mid-1930's, however, that the concept of a universal modern architectural style was accepted as a tenable hypothesis and the modernist theory of site planning began to impose a new kind of uniformity on city design. The Congres Internationaux d'Architecture Moderne (C.I.A.M.), founded in 1928, brought together leading modernist architects of Europe, including Gropius, Mies and Le Corbusier. The fourth C.I.A.M. meeting, of which Le Corbusier was an influential organizer, adopted a series of statements of principles about city planning. Four critical areas of city planning were identified as dwellings, recreation, workplaces, and transportation. Although the tall building was officially adopted by C.I.A.M. as a basic design element of cities, Barnett points out that actual European housing projects were always in row houses or walk-up apartments. ${ }^{13}$ The prototype of the skyscraper capriciously interjected into the existing fabric of the city, while certainly not the original intention of C.I.A.M., has ingrained itself as the pattern of urban development throughout the twentieth century.

The excesses of modernism, the intrusive disruption of the traditional urban fabric with the careless introduction of the skyscraper, the decentralization of urban and civic spaces, and the deterioration of the street and pedestrian scale, have led the brothers Krier to reassess patterns of urban building. Both Rob and Leon Krier reject the concept of the tabla rasa as espoused by the C.I.A.M. conferences and generally accepted as the raison d'etre of urban planning. Instead, Rob Krier presents three theorems which serve as the basis for his own city planning proposals. First, Krier writes, each building in a town must be subordinate to the overall plan in terms of scale, building type, and architectural vocabulary. Se cond, the existing conception of urban space must not be destroyed, but com plemented by new building. And, final ly, the terms "regular" and "irregular" in the context of the urban fabric and building form, should not be postulated on any ideological grounds..$^{14}$ As an example, Krier points to the introduction of the orthogonal town-plan in Greece and its imitation in new urban settlements and during the same period, towns that were built on an irregular ground plan. History shows that architectural and spatial masterpieces were produced by both types.

In his critical assessment of the Wexne Center, R.E. Somol focuses upon Eisen man's initial archeological excavation of the site which provide the impetus for the reconstruction of the fragments of the armory. Somol recounts the analogy of the burrow and the castle to the writings of Kafka, where the castle and the burrow become emblems for the multiple passageways and connections of the labyrinth, and the act of castling in chess, where two pieces are simultaeously in motion, passing through one another and reversing positions.

At Wexner, the sovereign grid (reason) is allowed a doubling twostep with the rook, suspending the laws of normal movement and development. This process produces a third term for the avantgarde object, between the sphere and the labyrinth, where the becoming-grid of the castle and the becoming-castle of the grid produce an imperceptibility. The 'final' structure exists in a state of between, a supplement to architec- ture, part landscape and part scaffold.$^{15}$

Like Calvino's contrast of the postcard view of romantic/nostalgic memory of the displaced city versus the cold reality of its present condition, the historicist visions of the Kriers' require the critical reasessment of the attributes (the street, the square) or the traditional, monumental city and require their assimilation into the fabric of the modern city. Neither Rob nor Leon Krier would accept Eisenman's existential condition of dislocation as the raison d'etre of architecture or urban planning. However, they certainly would not object to Rossi's analogy of the house and the collective memory of the city. Whereas Eisenman's excavations unearth not only the memory of the site itself (i.e.: pre-existing building foundations), they also unearth the collective memory or psychological condition of the site which links it to a broader, universal collective memory (i.e.: the mercator grid) ${ }^{16}$ Eisenman's polemical position, therefore, presents the architect with an irreconcilable psycho/philosophical condition in which the memory of the site (past, present, and future) is a simultaneous condition of the site, but cannot be individually invoked without abrogating (or "dislocating") some "other" condition. From Eisenman's point of view, the issues of "modernism" versus "historicism" are a mute point because the existential condition of "post-modern" man (and, by extension, the "post-modern" city) is indeterminate and nonabsolute.

As the parabolic surface of the negative mirror focuses that which is reflected to a unique point and yields a previously unknown image the "house" of the city becomes the repository of collective memory and, like the negative mirror, reveals the apparantly isolated and disconnected facets of place and focuses them together in a more intense reality. Calvino's postcard image of the city of the past is held captive by its own memory; a transient moment dislocated from the reality of the present. A frozen instant in time, it is a specific place or locus part of the seemless continuity of time, yet disconnected and separate. Like images superimposed upon a screen, past and present fuse into a singular image; separable yet composite; a synthetic image of place both present and remembered. Calvino's postcard, then, is a mnemonic device which recollects the past and dislocates the moment from the continuum of time.

For Rossi the European city has become the house of the dead. ${ }^{17}$ Its history, its function, has ended; it has erased the specific memories of the houses of in dividual childhood to become a locus of collective memory. Rossi employs the image of the house as an analogue to the city. Analogy allows for both memory and history mixing "autobiography and civic history." individual and collective. ${ }^{18}$ Whereas the bourgeois house of Rossi's childhood permitted fantasy, it denied the ordering of type; that apparatus codifying the city in such a way that, in spite of bistory, memory can imagine and reconstruct a future time of fantasy. Thus, memory is set into motion through the in ventive potential of the typological apparatus, the analogous design process (in Rossi's case, the "analogous city" is a manifestation of both his writings and his drawings) 19

\section{Critical Memory}

There came a period when the charm radiated by old towns was not so harmless, for it might lead one to believe that the architect's ambitions did not go beyond the decorative aspect, that a picturesque backdrop was all that was needed.

\section{- Fritz Schumacher}

In the catalogue of the International Building Exbibition Berlin 1987: Examples of a New Arcbitecture, Joseph Paul Kleihues discusses the critical reconstruction of the city and takes issue with the nostalgic tendencies of present-day historicism. In Kleihues' view, "Postmodernism," "Neoclassicism," and "Neoromanticism" 
are symptomatic expressions of escape from an industrial way of life and a "flight into the illusionary world of theatrical scenery." ${ }^{20}$ Architecture and town planning just cannot be reduced to the denominator of functionalism and rationalism. Wherever they are permitted to operate as incipient and adventurous art they combine the constructive rationality with the power of the poetic, they become what Holderlin called a "transcendent design of man abiding in his merit and his spirit of poetry."21

In the IBA competition in Berlin, Charles Moore's winning urban landscape and Leon Krier's "little town by the waterfront" proposal for the Tegel lake and woods district on the outskirts of the city evoke memories of ancient cities firmly rooted in the ground plan and enhanced by piaz$\mathrm{za}$ and street perspectives. The idealistic concept proselytized by Krier and has characterized his drawings with their historical emphasis and nostalgia is underscored by Krier's unwavering adherence to classicism

The public buildings must be constructed to the highest standards of craftsmanship and technology. Classical architecture found the definitive answer to all the problems in this field. Not only did we employ a scale that gives an urban district a pleasant and familiar at mosphere, we also tried to give the buildings that special imprint which alone makes a location into a real, unique locality. ${ }^{22}$

In Moore's Recreational and Residential Facilities proposal for the Tegel Docks area, water became the unifying element connecting the individual parts. To Moore, it is the specific relationships of parts to whole and the relationship of the complex in plan and scale to the site that contributes to the "unique locality":

Admittedly, we have designed the cultural institutions, leisure facilities and dwelling-houses as their arrangement of the site they constitute parts of a whole, relating to each other and enhancing each other ... The urban areas where we live, and which we remember, are localities defined by the interaction of the individual elements building, water, and landscape. ${ }^{23}$

Both Krier and Moore would appear to concur that memory is not embodied in any individual component of the site, but rather, it is the composition of the multifarious components and their relationship to the site and context ("locality") in which the collective memory is in vested. According to Kleihues in a state ment which seems to parallel Rossi's at titude, the topographic layout of the historical city no longer exists. In spite of the brutal acts of destruction and disrup tive interventions within the context of the city, it is the urban ground-plan that of fers the most clues to its origins. Over the centuries, conventions having universal character have evolved for architecture and urban development. Nevertheless,
The city is a three-dimensional model and, as a corporeal manifestation of the collective memory through its composition of individual elements, is inextricably integrated with its ground-plan. However, the ground-plan is a passive regulator of the organization of buildings in regard to the changing types and styles of buildings that are erected upon it. Whatever program the ground-plan lays down, it will not take definite shape until a superstructure has been erected: streets, conjunction with the urban planning program. Therefore, Kleihues asserts, it is the image of the city, the constituent parts as well as the whole, especially the physiognomy of its houses, that transcending the geometry of the city reveals the spiritual and cultural values of changing epochs.

Kleihues embraces the Greek concept of techne which has a double function of both skill (craft) and art (aesthetic). As such, it is the instrument of rationality and allows imaginative emancipation (exsquares and parks only come to life in

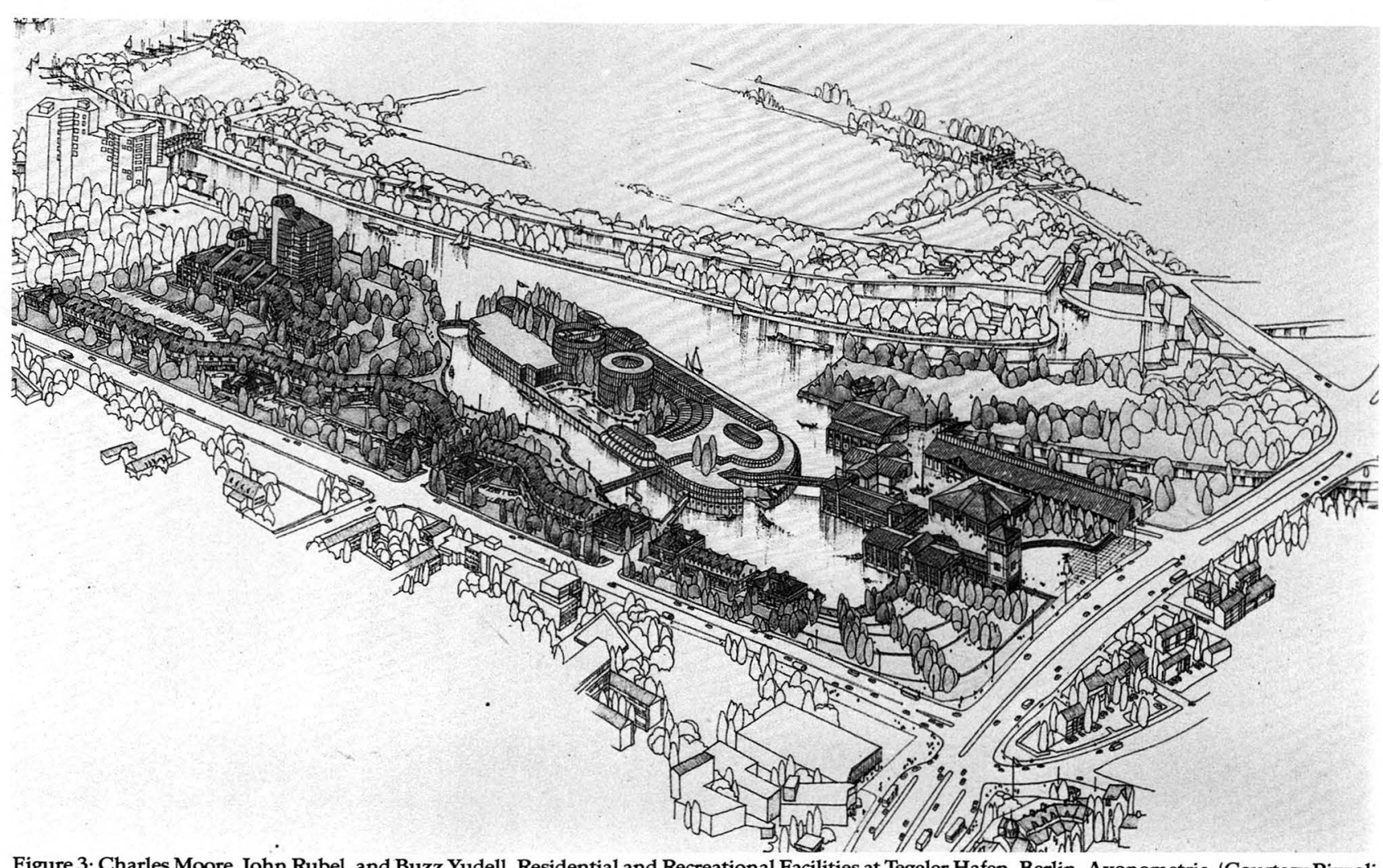

Figure 3: Charles Moore, John Rubel, and Buzz Yudell, Residential and Recreational Facilities at Tegeler Hafen, Berlin, Axonometric. (Courtesy Rizzol International Publications). 
pression of "poiesis"). In terms of Freud's metapsychology, transmission of ideas involves three moments: "repetition," "remembrance," and "working through" which is a liberating and separating process. Although critical reconstruction involves an interest in the past, it embodies the dialectic between "separation" and "restoration" and seeks emancipation on new terms without romanticizing repetition.

In critical memory the references are historic; however, the mnemonic device (syntactic referents) are divested of their symbolic and iconographic connotations and, thereby, acquire new semiotic meaning. In the European city, context and memory are defined as a vertical phenomenon. The new is built upon the site and superimposed upon the foundations of the old, sometimes literally retracing the footprint of the past. Memory persists through the vertical translation of the past into the present and continuity is assured for the future. Critical memory, therefore, is not simply the recreation of the past, but a non-nostalgic emancipation of the past through telenomic in tervention and transmission.
1. Norberg-Schulz, Christian, Genius Loci: Towards a Phenomonology of Arcbitecture, Rizolli International Publications, New York, 1980, p. 8

2. Rossi, Aldo, The Architecture of the City, The MIT Press, Cambridge, Massachusetts, 1982, p. 3.

3. Ibid., pp. 7-8

4. Ibid., p. 7.

5. Fisher, Thomas, "Eisenman Builds: Introduction, Progressive Architecture 10:89, p. 68

6. Barnett, Jonathan, The Elusive City: Five Centurie of Design. Ambition and Miscalculation. Harpe Row, Publishers, New York, 1986, p. 38

7. Ibid., p. 37

8. Barnett recounts Krier's architectural evolution: By contrast, monumental city design, not long ago discarded as an irrelavent and outmoded se of ideas, has been gaining new interest. Leo Krier ... began his monumental planning concepts as a reaction to the megastructure, but also in evolution from it. Straight lines of communication typical of megastructure design became a monumental axis. This transition is clearly visible in Krier's Leinfelden City Center project o 1971, where the main and cross axes are line with continuous, large-scale buildings, and the intersection of the two axes is the site for a cluste of what looks like four modern office buildings. Krier in his more recent projects resolutely refuses to deal definitively either with groups of tall buildings or with automobiles, which end up being excluded from his monumental-city concepts (p. 190).

9. Barnett op cit. p. 38

10. Ibid., p. 186.
11. Krier, Rob, Urban Space, Rizzoli International Publications, Incorporated, p. 64

12. Barnett notes that Le Corbusier was a great artis who was able to capture the promise and the excitement of modernity in extraordinarily authoratative images, but the images were no based on the functional, organizational or economic priorities of real cities. His 1935 revision of his theoretical city, La Ville Radieuse, in its social structure, reflected the authoritaria organization advocated by the syndicalists. Its plan had a new anthropomorphic appearance. with an administrative head (the familiar cluste of cross-shaped towers), a residential body with commercial-district viscera, workers' housing for legs and factories for feet. The influence of the recently adopted C.I.A.M. principles may perhaps be seen in the increasing articulation of separate districts, but the nature and placement of these districts did not correspond to the functional organization of existing cities.

13. Barnett, op. cit., p. 120

14. Krier, op. cit., p. 66

15. Somol, R.E., "O-O", Progressive Architecture 10:89.

16. In his residential project for the Southern Friedrichstadt district of Berlin near Check Poin Charlie, Eisenman "excavated" the site and superimposed two grids; the existing urban grid of the district and the mercator grid which was "revealed" in the excavation. Eisenman then proceeded to use the layered grids to organize the site and building footprint and, by tilting the grids vertically, using them to define the compositional matrix of the elevations. The ground-plane grids alternately create elevated walkways, walls, and preserve and define the excavation of the site. Eisenman's elablorate "reconstruction" of the ground-plane was not executed.

17. Rossi, op. cit., p. 10

18. Ibid., p. 9.

19. Rossi cites the Quatremere de Quincy's definition of type:

The word 'type' represents not so much the image of a thing to be copied or perfectly imitated as the idea of an element that must itself serve as the rule for the model ... The model, understood in terms of the practical execution of art, is an object that must be repeated such as it is; type, on the contrary, is an object according to which one can conceive works that do not resemble one another at all (p. 40).

20. Kleihues, Joseph Paul, International Building Exbibition Berlin 1987: Examples of a New Arcbitecture, DAM, Frankfurt am Main, 1986, p. 15.

21. Ibid., p. 57

22. Ibid., p. 14.

23. Ibid., p. 14

24. Ibid. P. 15 